\title{
Correction to: Decomposing Legal Personhood
}

\author{
Jon Garthoff ${ }^{1}$
}

Published online: 4 September 2018

(c) Springer Nature B.V. 2018

\section{Correction to: Journal of Business Ethics}

https://doi.org/10.1007/s10551-018-3888-0

The Acknowledgment section of this article was inadvertently misprinted. The following sentence should have concluded the Acknowledgment:

Above all I would like to thank Spenser Powell. This essay would not have been possible without the many conversations we shared as he composed his exceptional undergraduate thesis, Equality of Participation, at the University of Tennessee.

We deeply regret this omission.

1 Department of Philosophy, University of Tennessee, 801 McClung Tower, Knoxville, TN 37996-0480, USA 